\author{
В. І. Богорад ${ }^{1}$, Т. В. Литвинська ${ }^{1}$, \\ А. В. Носовський ${ }^{1}$, В. Ф. Рязанцев ${ }^{2}$, \\ Р. Ф. Тріпайло
}

'Державний науково-технічний центр з ядерної та радіаційної безпеки

?:Державний комітет ядерного регулювання України

\section{Аналіз національних} та міжнародних

\section{вимог з безпеки}

\section{при використанні}

джерел іонізуючих

\section{випромінювань}

\section{у гамма-дефектоскопії}

Представлено результати аналізу сучасної практичної діяльності з радіонуклідної, дефектоскопії, вітчизняних норм та правил, міжнародних стандартів та рекомендацій Міжнародної комісії з радіологічного захисту та Міжнародного агентства з атомної енергії, які в подальшому можуть бути застосовані для вдосконалення національних вимог з безпеки в гамма-дефектоскопіі.

В. И. Богорад, Т. В. Литвинская, А. В. Носовский, В. Ф. Рязанцев, Р. Ф. Трипайло

\section{Анализ национальных и международных требований по безопасности при использовании источников ионизи- рующих излучений в гамма-дефектоскопии}

Представлены результаты анализа современной практической деятельности в области радионуклидной дефектоскопии, отечественных норм и правил, международных стандартов и рекомендаций Международной комиссии по радиологической защите и Международного агентства по атомной энергии, которые в дальнейшем могут быть использованы для усовершенствования национальных требований по безопасности в гамма-дефектоскопии.

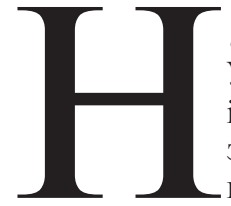
а даний час в різних галузях господарства Україні використовується понад 20 тис. джерел іонізуючого випромінювання (ДїВ). Діяльність з ДіВ, що підлягає ліцензуванню й державному нагляду, провадить біля 4 тис. підприємств, організацій та установ. До числа таких організацій входить більшість підприємств металургійної, вугільної, машинобудівної промисловості, будівельні та гірничо-геологічні підприємства, підприємства паливно-енергетичного комплексу, академічні та галузеві науково-дослідні організації, медичні установи тощо. Виняткове різноманіття використовуваних радіаційних джерел і наявність при цьому істотних особливостей забезпечення радіаційної безпеки в процесі їх експлуатації обумовлює потребу в нормативному та методичному забезпеченні такої діяльності. Забезпечення безпечного використання ДїВ є однією з пріоритетних задач Державного комітету ядерного регулювання України (Держатомрегулювання) як органу регулювання ядерної та радіаційної безпеки.

Розвиток сучасних наукових знань в галузі радіаційної безпеки, великий досвід застосування ДЇВ, розвиток нормативно-правової бази є підгрунтям для перегляду старих та розробки нових документів з регулювання безпеки ДїВ.

Метою статті є встановлення дефіциту в сфері національного нормативного регулювання діяльності з використання джерел іонізуючого випромінювання в промисловій дефектоскопії.

\section{Загальні відомості про гамма-дефектоскопи}

Для гамма-дефектоскопії найбільше застосування одержали радіонукліди кобальт-60, цезій-137, іридій-192, селен-75, тулій-170; застосовуються також джерела на основі європія-152, європія-154, європія-155, самарія-150, кадмія-153.

Герметизуючі оболонки джерел виготовляють з твердих матеріалів, що мають механічну, термічну й корозійну стійкість.

Гамма-дефектоскопи є пристроями з радіонуклідним джерелом гамма-випромінювання, системою керування випуском і перекриттям пучка випромінювання, системою сигналізації про положення джерела або затвора, системою блокування, що запобігає можливості опромінення персоналу, і засобами орієнтації пучка випромінювання щодо контрольованого об'єкта.

У більшості гамма-дефектоскопів застосовують механічну систему сигналізації (покажчиком положення просвічування служать рукоятка приводу, розташована на радіаційній голівці дефектоскопа, сигнальний прапорець і т. д.), але існують дефектоскопи, в яких використовуються кілька способів сигналізації (світлова, механічна, радіометрична).

Для виключення можливості випуску джерела випромінювання сторонньою особою, в гамма-дефектоскопах застосовують механічне блокування (замок з ключем, упор на виході з радіаційної головки).

У багатьох гамма-дефектоскопах контроль часу просвічування виробу здійснюється за допомогою реле часу, яке не тільки сигналізує про закінчення просвічування, але й управляє випуском і перекриттям пучка випромінювання.

У гамма-дефектоскопах великої потужності передбачено системи аварійного повернення джерела в положення зберігання. В аварійних ситуаціях (падіння тиску в пневмосистемі, відключення електроживлення тощо) за допомогою 
пружинного приводу затвор автоматично закривається або джерело переводиться в положення зберігання.

При гамма-дефектоскопії використовуються різні пристрої для формування й орієнтації пучка випромінювання щодо просвічуваного виробу (діафрагми, колімаційні головки і т. д.); це дає змогу проводити підготовчі роботи на безпечній відстані від радіаційної головки, а під час просвічування зменшувати інтенсивність розсіяного випромінювання в місці просвічування і на робочих місцях персоналу.

Для збільшення продуктивності контролю зварені шви трубопроводів просвічують кільцевим пучком (джерело випромінювання розташовують усередині труби), застосовуючи автоматизовані й механізовані комплекси.

Залежно від умов застосування радіаційні дефектоскопи поділяють на стаціонарні (застосовуються в спеціально обладнаних приміщеннях - дефектоскопічних лабораторіях) та пересувні й переносні.

За формою пучка випромінювання розрізняють такі радіаційні дефектоскопи:

фронтальні, призначені для просвічування виробів спрямованим пучком випромінювання з кутом виходу $\alpha$, меншим за $2 \pi$ (наприклад, просвічування пірамідальним або конічним пучком випромінювання);

панорамні, призначені для просвічування виробу пучком випромінювання з кутом $\alpha \geq 2 \pi$ (наприклад, просвічування кільцевим або сферичним пучком випромінювання);

універсальні, використовувані для фронтального й панорамного просвічування.

Заряджання (перезаряджання) радіоізотопних дефектоскопів проводять для заміни джерел випромінювання, активність яких згодом значно зменшується внаслідок радіоактивного розпаду, а також коли дефектоскоп необхідно тимчасово розрядити для проведення ремонтно-профілактичних робіт. Дефектоскопи заряджають безпосередньо на місці експлуатації (із застосуванням транспортно-перевантажувальних контейнерів - ТПК) або на спеціалізованих підприємствах, обладнаних необхідними пристосуваннями: дистанційними захоплювачами, захисними екранами, перевантажувальними колодязями тощо.

Заряджання дефектоскопів джерелами випромінювання можна проводити водним, сухим і комбінованим способами. При водному способі заряджання здійснюють під захисним шаром води в перевантажувальних колодязях, користуючись дистанційними захоплювачами і спеціальними приладами. Сухим способом дефектоскопи заряджають за допомогою ТПК. Цю операцію проводять за захисними екранами, застосовуючи маніпулятори або захоплювачі, а також безпосередньо з транспортного контейнера із застосуванням дистанційних пристосувань. При заряджанні дефектоскопів комбінованим способом частину операцій (наприклад, розвантаження транспортних контейнерів) виконують водним способом (під захисним шаром води в колодязі), а інші операції - сухим (за захисним екраном із застосуванням проміжного контейнера).

Захист гамма-дефектоскопів має забезпечувати зниження потужності експозиційної дози випромінювання до допустимих рівнів. Біологічний захист стаціонарних, пересувних і переносних дефектоскопів виготовляють з матеріалів, які мають високий атомний номер (свинцю, вольфрамових сплавів та ін.).

Конструкція радіоізотопних дефектоскопів повинна забезпечувати радіаційну безпеку при пожежі, для чого легкоплавкі захисні матеріали вміщують у кожухи з тугоплавких матеріалів, що виключають можливість плавлення матеріалу захисту або зсуви джерела з положення зберігання.
Для безпечної експлуатації дефектоскопів необхідно контролювати якість захисних пристроїв. Перевірка якості захисту дефектоскопів проводиться в положенні зберігання джерела випромінювання.

При розробці конструкції дефектоскопів потрібно враховувати їхнє призначення, тому шо вимоги до захисту стаціонарних і пересувних, а особливо переносних дефектоскопів відрізняються. Конструкція останніх має забезпечувати можливість їхнього транспортування й технологічну маневреність у різноманітних умовах виробництва.

\section{Нормативне забезпечення безпеки діяльності}

Основним документом, що регламентує забезпечення безпеки при проведенні діяльності з дефектоскопії на сьогоднішній день, $є$ «Санитарные правила по радиоизотопной дефектоскопии» [1]. Цей документ був розроблений у 1970-х роках. Він визначає основні правила поводження з ДіВ при організації та проведенні робіт з радіонуклідної дефектоскопії, включаючи встановлення допустимих значень радіаційних параметрів для різних режимів експлуатації, вимоги до заряджання і (або) перезаряджання, заходи та засоби індивідуального захисту персоналу, вимоги до радіаційного контролю, улаштування сховищ. Проте за більш як 30-річний проміжок часу з'явилися нові знання щодо впливів іонізуючих випромінювань на людину і навколишнє середовище, запроваджено нові технології з використанням ДІВ, встановлено нові принципи нормування шкідливих факторів і впливів, внаслідок чого нормативно-правова база в сфері поводження з ДІВ набула значного розвитку.

Так, у 1997 р. вийшли нові «Норми радіаційної безпеки України» (НРБУ-97) [2], якими встановлено три основні принципи радіаційного захисту: виправданості, неперевищення, оптимізації. Зокрема, НРБУ-97 запроваджено систему радіаційно-гігієнічних регламентів, для яких встановлено відповідні дозові обмеження. Зменшено ліміти доз опромінення персоналу та населення. Встановлено систему допустимих рівнів радіаційних параметрів, що характеризують шляхи формування доз опромінення. Введено поняття ризику в сфері регулювання радіаційної безпеки.

У 2005 р. введено в дію нові «Основні санітарні правила забезпечення радіаційної безпеки України» [3], розроблені, як і [2], на базі нових рекомендацій міжнародних організацій МКРЗ та МАГАТЕ. [4]. Дані санітарні правила встановлюють вимоги до безпечного поводження з відкритими та закритими ДїВ, включаючи проектування, експлуатацію, зберігання. Документом визначено вимоги до системи радіаційно-дозиметричного контролю, служб радіаційної безпеки, ведення обліку дозових показників, облаштування приміщень, в яких проводяться роботи з ДІВ, встановлення відповідальності, інструктивно-методичної документації. Сформульовано ряд вимог у термінах неперевищення радіаційних параметрів для конкретних установок (джерел), зокрема щодо робіт з дефектоскопами.

До того ж в Україні запроваджено систему ліцензування діяльності в сфері використання ядерної енергії, яка розповсюджується і на діяльність з використання ДЇВ. Відповідно набула розвитку і нормативна база, що регулює дану сферу. Набрали чинності такі документи, як:

НП 306.5.05/2.065-02. Вимоги та умови безпеки (ліцензійні умови) провадження діяльності з використання джерел іонізуючого випромінювання [5]; 
НП 306.5.05/2.066-02. Вимоги до звіту про аналіз безпеки провадження діяльності з використання джерел іонізуючого випромінювання [6];

НП 306.6.124-2006. Правила ядерної та радіаційної безпеки при перевезенні радіоактивних матеріалів (ПБПРМ-2006) [7];

НП 306.4.08/1.042-00. Правила забезпечення збереження ядерних матеріалів, радіоактивних відходів, інших джерел іонізуючого випромінювання [8].

НП 306.5.05/2.065-02 [5] встановлює умови проведення ліцензіатом діяльності з використання ДїВ та вимоги щодо забезпечення їх безпечної експлуатації. Зокрема, визначено вимоги щодо забезпечення фінансовими та людськими ресурсами, вимоги стосовно біологічного захисту ДїВ, підготовки та навчання персоналу, аналізу доз опромінення персоналу, вимоги до щорічного звіту з безпеки тощо. Проте даним документом не враховано специфіку конкретних ДІВ та умов їх використання в різних галузях застосування, тому в розвиток даного документа розроблюються ліцензійні умови та вимоги для різних сфер використання ДІВВ (медицини, дефектоскопії тощо).

3 поширенням застосування ДЇВ у промисловості та медицині більше уваги аспектам безпеки приділяється з боку МАГАТЕ. Так, новий документ «Radiation Safety in Industrial Radiography» [9], який базується на сучасних підходах до забезпечення радіаційного захисту персоналу, населення та навколишнього середовища, визначає ряд засад з безпечного використання джерел іонізуючого випромінювання в індустрії. Зокрема, в документі розглянуто такі аспекти, як управління безпекою та культура безпеки, контроль за джерелами, програма радіаційного захисту, моніторинг індивідуальний та робочих місць, зонування, системи сигналізації та блокування, маркування, перевірка та калібрування, використання контейнерів із збідненого урану, транспортування та збереження ДІВВ, програма нагляду за здоров'ям персоналу, система управління якістю, нагляд та інспектування, аварійна готовність, підвищення кваліфікації та тренування тощо.

Значну увагу захисту працівників від дії іонізуючого випромінювання приділено в директивах Європейського Союзу (далі - Директиви). Основні положення щодо забезпечення безпеки від впливу радіації містяться в Директиві 96/29/Євратом від 13 травня 1996 р. «Основні стандарти безпеки для захисту здоров'я працівників та населення від небезпеки, що виникає від іонізуючої радіації», Директиві 90/641/Євратом від 4 грудня 1990 р. «Про захист робітників, що працюють по найму, схильних до ризику проникаючої радіації протягом їх роботи в контрольованих зонах», Директиві 96/618/Euratom від 27 листопада 1989 р. «ذнформування широкої громадськості про заходи охорони здоров'я, що мають вживатися, та дії, які повинні виконуватись у випадку радіаційної аварії, Директиві 2003/122/Євратом від 22 грудня 2003 р. «Про контроль над закритими джерелами високого радіоактивного випромінювання і кинутими джерелами». Даними документами встановлено як обмеження граничних доз опромінення персоналу та населення, так і вимоги щодо організації робочих місць, моніторингу, захисних заходів, ведення записів, медичного обстеження працівників, інформування, реагування на радіаційні аварії. Визначено категорії персоналу, шо працює з ДІВВ, регламентовано положення щодо інформації про індивідуальні дози опромінення працівників (записи, облік, бази даних), інформування громадськості у випадку радіаційних аварій тощо.

Отже, з моменту введення в дію документа, що визначає правила безпеки в радіоізотопній дефектоскопії, роз- роблено нові підходи до регламентації опромінення персоналу та населення, дозові ліміти стали жорсткішими. 3'явилися нові вимоги до забезпечення безпеки при поводженні з ДЇВ та нові підходи до регулювання безпеки. Все це потребує розвитку та вдосконалення нормативної бази в сфері поводження з ДЇВ, а сучасні вимоги та рекомендації з радіаційної безпеки мають знайти відображення в положеннях нових документів, шо регулюють безпеку використання ДЇВ у радіонуклідній дефектоскопії.

\section{Забезпечення безпеки при радіаційній дефектоскопії}

Організація праці дефектоскопістів залежить від типу застосовуваних джерел випромінювання, особливостей технології просвічування виробів, розміщення дефектоскопів і планувальних рішень, системи радіаційного захисту й інших факторів. Комплекс технічних, організаційних і санітарногігієнічних заходів, спрямованих на забезпечення безпеки при радіаційній дефектоскопії, являє собою систему, яка схематично представлена на рис. 1, 2 і 3.

Контроль за дотриманням вимог безпеки здійснюється як на стадії проектування (експертиза технічної документації на дефектоскопи й дефектоскопічні лабораторії тощо), так і на стадіях спорудження або виготовлення установок та їхньої експлуатації (контроль якості захисних споруджень, дефектоскопів й ін.).

Дози опромінення персоналу, що проводить заряджання, перезаряджання й ремонтно-профілактичні роботи, формуються зовнішніми полями випромінювання, створюваними радіонуклідними джерелами і радіоактивним забрудненням виробничого устаткування та робочих поверхонь, а також при попаданні нуклідів до організму (надійна герметизація радіонуклідних гамма-джерел робить останній фактор малоймовірним - таке може статися лише при радіаційних аваріях).

Для обгрунтування заходів щодо забезпечення радіаційної безпеки при дефектоскопії важливо правильно оцінювати можливі індивідуальні дози опромінення персоналу, а тому потрібно знати закономірності формування поля іонізуючого випромінювання при роботі з дефектоскопом. Основними характеристиками радіаційного поля $є$ енергія випромінювання і просторовий розподіл потужності експозиційної дози випромінювання.

Розрахункові методи визначення дози на теперішній час достатньо добре розроблені, однак трудомісткі, особливо при оцінці параметрів просторового кутового розподілу випромінювання. Тому на практиці виміряють потужність експозиційної дози гамма-випромінювання за час $t$ у різних точках простору навколо дефектоскопа при різних умовах просвічування і на підставі отриманих результатів роблять оцінку можливого рівня опромінення дефектоскопістів.

При заряджанні гамма-дефектоскопів доза опромінення персоналу складається з доз опромінення, одержаних під час виконання різних операцій. Для переносних і пересувних дефектоскопів таких основних операцій три: транспортування контейнера 3 джерелом зі сховища до місця заряджання (на візку, вручну); виймання джерела з контейнера і вміщення його в радіаційну головку; транспортування зарядженого дефектоскопа в сховище.

Тривалість окремих операцій під час заряджання визначають хронометражем. Потужність експозиційної дози вимірюють на робочих місцях персоналу на рівні грудей, таза, 


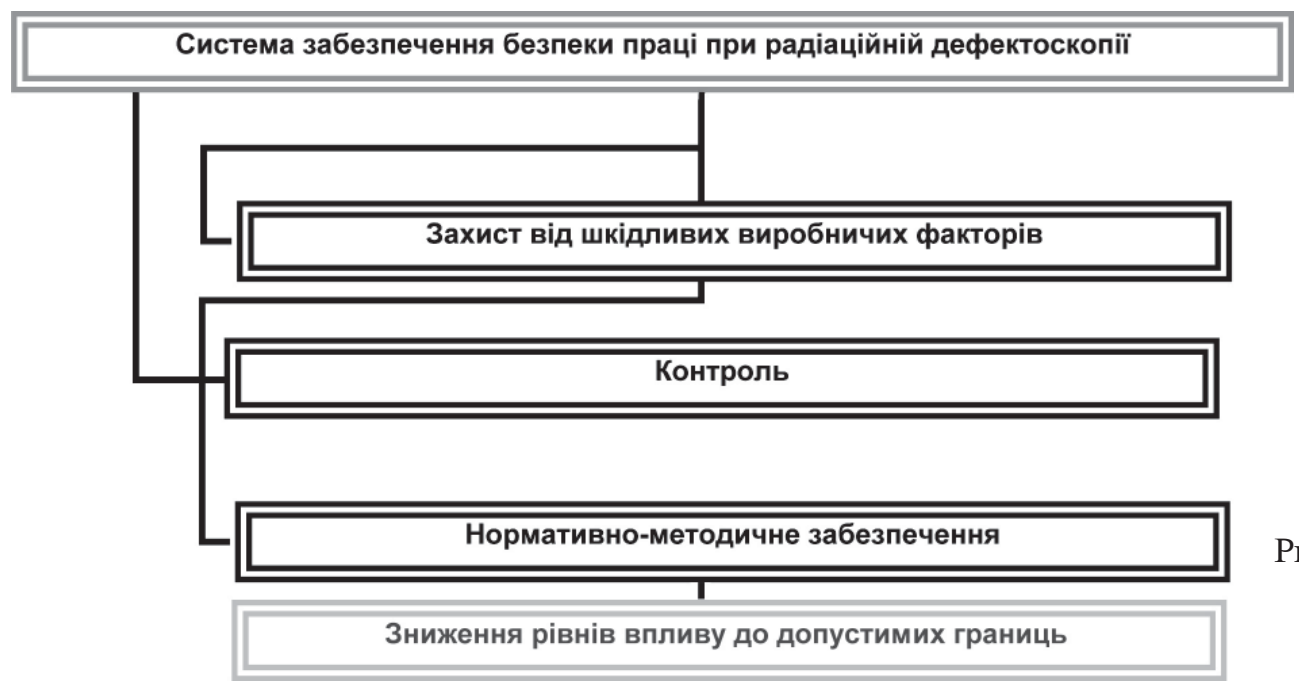

Рис. 1. Схематичне зображення системи радіаційної безпеки

при проведенні дефектоскопічних робіт

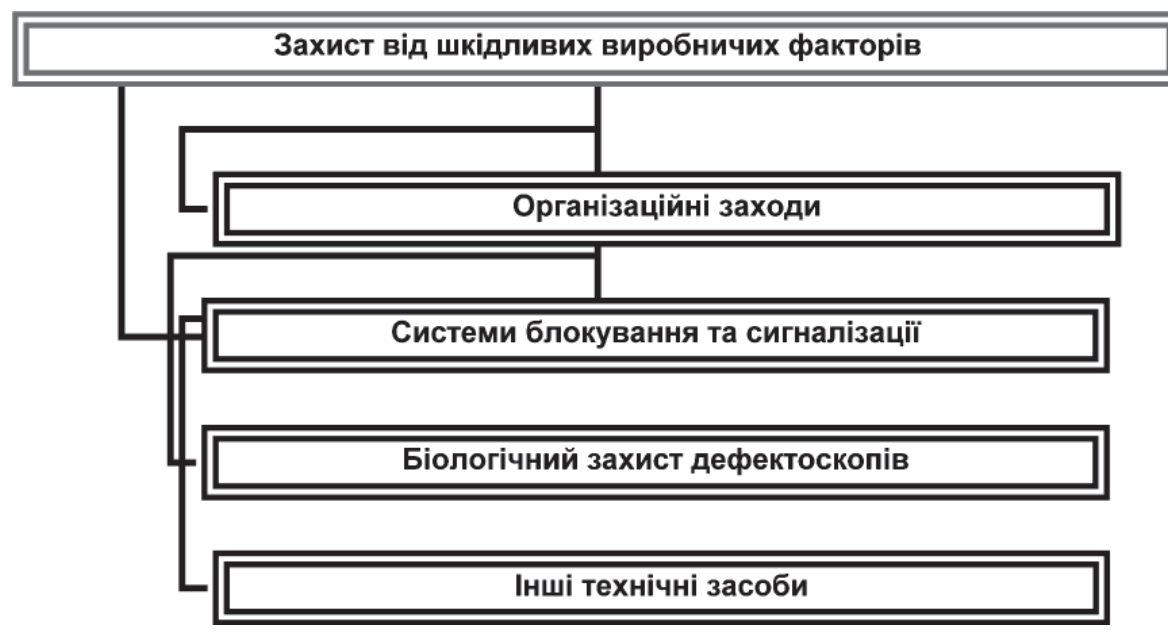

Рис. 2. Схематичне зображення заходів та засобів з безпеки при проведенні дефектоскопічних робіт

голови, а також кистей рук. Отримані в такий спосіб дані про розподіл дозового поля при виконанні зазначених робіт дають змогу підійти до встановлення радіаційно-небезпечної зони і орієнтовно судити про можливі індивідуальні дози опромінення персоналу.

Заряджання значної частини переносних і пересувних гамма-дефектоскопів радіонуклідними джерелами здійснюється або за захисними екранами, або із застосуванням подовжених маніпуляторів.

Експериментальні дані показують, що при транспортуванні вручну гамма-дефектоскопа або контейнера з джерелом випромінювання найбільшому опроміненню піддаються стегна, кисті рук і таз, а під час вилучення джерела 3 контейнера і вміщення його в радіаційну головку - кисті рук і голова (при заряджанні за допомогою дистанційних інструментів і за захисним екраном відповідно).

При водному й сухому способах заряджання з використанням захисної камери дози опромінення персоналу в 510 разів менші за дози опромінення, отримані при використанні захисних екранів, однак останні найпоширеніші і зручніші.

Ремонтно-профілактичні роботи і перезарядження дефектоскопів об'єднані в одну групу, оскільки складаються з однотипних операцій: транспортування гамма-дефектоскопа до місця перезарядження або проведення ремонту; вилучення джерела з радіаційної головки й вмішення його в транс- портно-перезарядний контейнер (ТПК); транспортування ТПК у сховище; транспортування ТПК до місця зарядки дефектоскопа; вилучення джерела з контейнера і заряджання дефектоскопа; транспортування гамма-дефектоскопа до сховища. 3 цього переліку видно, що під час перезаряджання й проведення ремонту обсяг операцій збільшується вдвічі порівняно тільки із заряджанням дефектоскопа.

При заряджанні, перезаряджанні та ремонті найбільшому опроміненню піддаються груди, таз і кисті рук. Розміщення індивідуальних дозиметрів у всіх зазначених місцях тіла недоцільне і створює незручність при роботі. Звичайно ix розташовують на рівні грудей. Для визначення дози опромінення інших частин тіла встановлено взаємозв'язок дози опромінення на рівні грудей $D_{\Gamma}$, таза $D_{\text {т }}$ і кистей рук $D_{\mathrm{p}}$ :

$$
D_{\mathrm{T}}=\varepsilon_{\mathrm{T}} D_{\mathrm{T}} ; \quad D_{\mathrm{p}}=\varepsilon_{\mathrm{p}} D_{\mathrm{T}},
$$

де $\varepsilon_{\mathrm{T}}=2 \pm 0,5$ і $\varepsilon_{\mathrm{p}}=8 \pm 2-$ емпіричні коефіцієнти, отримані на основі експериментальних даних.

Вихід радіоактивних аерозолів внаслідок розгерметизації застосовуваних у дефектоскопах радіонуклідних джерел випромінювання в процесі експлуатації і радіоактивне забруднення їхніх оболонок, обумовлене технологією виготовлення, може призвести до забруднення середовища навколо дефектоскопів, робочих поверхонь, шкірного покрову та одягу персоналу. Сучасні дефектоскопи застосовують 
Рис. 3. Схематичне зображення заходів щодо контролю за вимогами безпеки при проведенні дефектоскопічних робіт

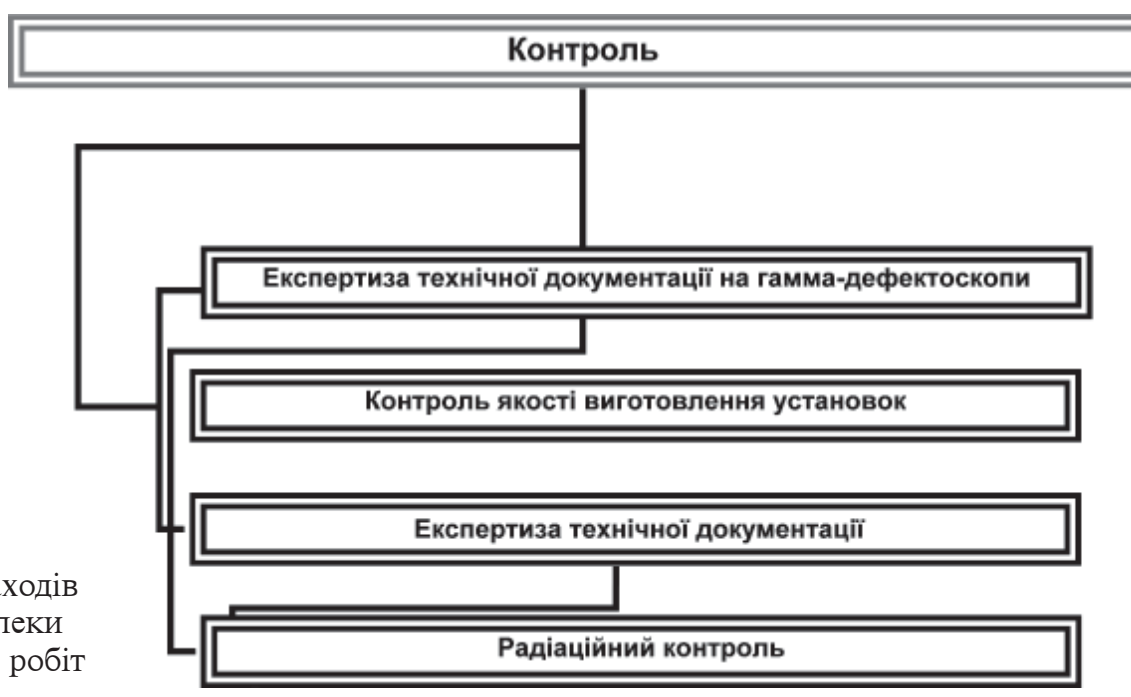

надійні системи герметизації радіонуклідних джерел випромінювання, тому можливість внутрішнього опромінення персоналу практично виключена. Але при заряджанні й ремонті таких пристроїв повністю виключити цей фактор небезпеки не можна.

Радіоактивне забруднення зовнішньої поверхні ампули герметичного джерела випромінювання можливе при його виготовленні, через недостатню дезактивацію поверхні ампули, а також у разі механічного контакту джерела із забрудненими поверхнями, наприклад у транспортних або перезарядних контейнерах. Забруднення робочих каналів гамма-дефектоскопів, транспортних і перезарядних контейнерів відбувається при терті забруднених радіоактивними речовинами ампул герметичних джерел випромінювання.

Радіоактивне забруднення робочих поверхонь може бути спричинене розбризкуванням води з колодязів дистанційним інструментом, перезарядними контейнерами, а також перенесенням радіоактивного забруднення на транспортних контейнерах. Рівні таких забруднень, як показала практика, можуть перебувати в межах $2 \cdot 10^{2} \div 1 \cdot 10^{4} \beta$-част./( $\left.\mathrm{cm}^{2} \cdot \mathrm{xв}\right)$.

Ремонт радіоізотопних дефектоскопів з невитягнутими джерелами випромінювань здійснюється в спеціально виділених примішеннях із застосуванням захисних пристроїв, що забезпечують зниження рівнів іонізуючих випромінювань до встановлених значень. Спеціальних вимог до обробки приміщень, призначених для заряджання (перезарядження) дефектоскопів із застосуванням ТПК, не висувається.

Заряджання (перезарядження) дефектоскопів проводиться тільки в присутності відповідальної особи служби радіаційної безпеки установи й обов'язково під безперервним радіаційним контролем. Категорично забороняється торкатися радіонуклідних джерел випромінювання руками. Заряджання (перезарядження) дефектоскопа джерелами випромінювання активністю більшою, ніж зазначено в паспорті заводу-виготовлювача, не допускається.

При заряджанні гамма-дефектоскопів водним способом слід приділяти увагу питанням планування виробничих приміщень і організації режиму роботи. Для попередження радіоактивного забруднення виробничих приміщень і устаткування під час заряджання гамма-дефектоскопів водним способом необхідне дотримання таких умов: неперевищення установлених технічними умовами норм забруднення радіоактивними речовинами поверхні радіонуклідних джерел; герметичність ампули джерела випромінювання, по- криття підлоги приміщення матеріалами, що легко дезактивуються (пластикатом, лінолеумом й ін.); покриття стін приміщення заряджання олійною фарбою або малосорбуючими матеріалами; обробка стін і дна колодязів з водою зсередини нержавіючою сталлю, а зовні - надійною гідроізоляцією; виготовлення устаткування з матеріалів, що легко дезактивуються і мають гладкі поверхні.

Природно, що у виробах різної форми по-різному відбувається ослаблення іонізуючого випромінювання і по-різному формується поле випромінювання за контрольованим виробом. У загальному випадку для формування поля випромінювання при просвічуванні виробів потрібні громіздкі розрахунки, що не завжди прийнятно в практиці радіаційної дефектоскопії. Крім того, при проведенні таких розрахунків необхідно залучати додаткову довідкову літературу для знаходження цілого ряду специфічних значень (альбедо випромінювання, дозових факторів накопичення).

Радіаційну дефектоскопію з використанням переносних гамма-дефектоскопів як технологічний процес можна представити у вигляді моделі, що описує всі основні підготовчі етапи цієї роботи і процес просвічування виробів (рис. 4). Доза опромінення дефектоскопіста формується при виконанні таких операцій: вилучення дефектоскопа зі сховища; транспортування дефектоскопа до місця просвічування; установка дефектоскопа для просвічування; просвічування виробу; зняття дефектоскопа; транспортування дефектоскопа в сховище; розмішення дефектоскопа в сховищі.

При просвічуванні в умовах відкритої площадки дефектоскопи доводиться переміщати в межах території підприємства (будмайданчика) на ручних візках, а на більші відстані за допомогою інших транспортних засобів.

Залежно від технології неруйнівного контролю і геометричних розмірів виробів, планування приміщень для просвічування та система радіаційного захисту мають бути різними. Найтиповіше примішення для проведення неруйнівного контролю якості виробів - робоча камера. Вхід і подача до неї виробів для контролю здійснюється через захисні двері.

Стаціонарні радіаційні дефектоскопи необхідно включати в ланцюг керування дверних блокувань, що вимикають високу напругу (переводять джерело в положення зберігання) при відкриванні дверей робочої камери. Повторно ввімкнути високу напругу (перевести джерело в робоче положення) слід тільки з пульта управління апарата після закриття дверей робочої камери. 


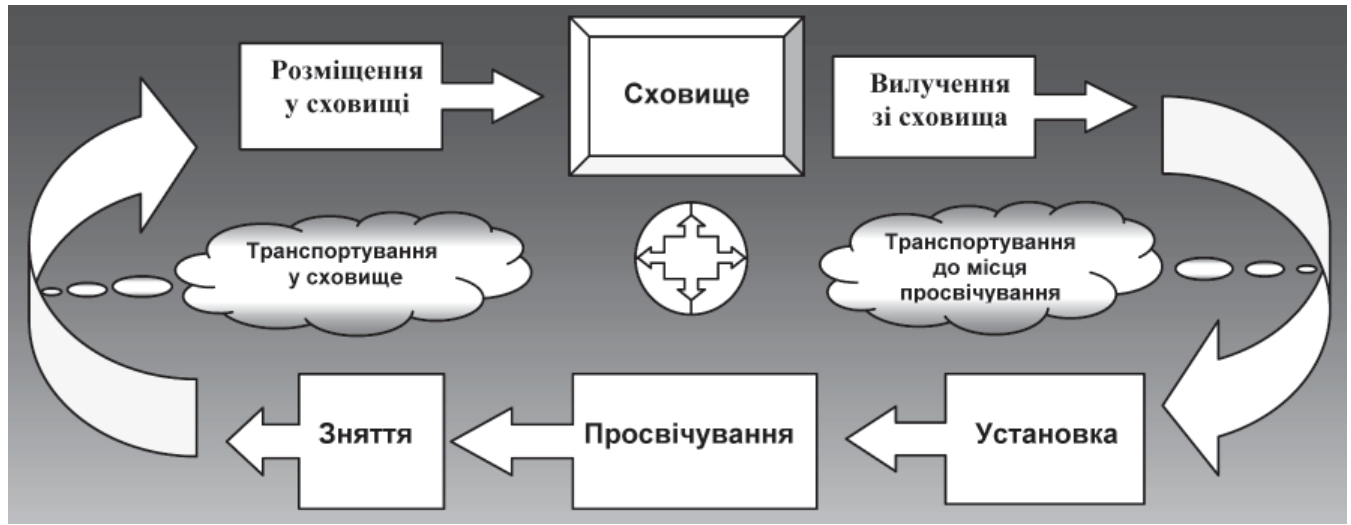

Рис. 4. Схема етапів роботи при проведенні радіаційної дефектоскопії

за допомогою переносних гамма-дефектоскопів

У робочій камері має бути встановлена звукова або світлова сигналізація, що попереджає про необхідність негайно покинути робочу камеру перед включенням апарата. Підлога робочої камери і пультової має бути зроблена з електроізолюючих матеріалів або покриватися на робочих місцях персоналу діелектричними килимками.

На пульті управління дефектоскопа і над входом до робочої камери встановлюється світлове табло з попереджуючими написами типу «Іде просвічування», які загоряються при включенні дефектоскопа (подача високої напруги або перекладання джерела в робоче положення) і вимикаються після закінчення просвічування.

Для забезпечення радіаційної безпеки при проведенні дефектоскопічних робіт споруджуються спеціальні приміщення-сховища, обладнані відповідно до норм і правил радіаційної безпеки.

Радіаційні аварії та радіаційні події, пов'язані з експлуатацією дефектоскопів, становлять 40 \% загальної кількості радіаційних аварій і радіаційних подій. Практично всі радіаційні аварії і радіаційні події в дефектоскопії призводять до зовнішнього опромінення, яке в ряді випадків перевищує установлені гранично допустимі дози.

За результатами аналізу радіаційних аварій і радіаційних подій у радіаційній дефектоскопії за останні кілька років, в тому числі по інших країнах (за даними [10]), можна виділити такі основні причини їх виникнення: відмова системи блокування і сигналізації; дія агресивних середовиш; стихійні лиха; порушення правил, інструкцій і норм; технологічні дефекти джерел; конструктивні, будівельні, технологічні дефекти; механічні й термічні впливи; відмова системи випуску й перекриття пучка випромінювання.

Практика розслідування причин аварій і подій, які мали місце в експлуатуючих гамма-дефектоскопи організаціях, показує, що їх можна розбити на три основні групи: технічні (конструктивні, технологічні) - 60 \%; порушення правил, норм, регламентів, посадових інструкцій тощо - $24 \%$; комбіновані, обумовлені дією декількох причин, - $16 \%$.

\section{Висновки}

В умовах все більшої відкритості суспільства, європейської та світової інтеграції регуляторні документи в сфері поводження з ДЇВ мають бути гармонізовані з документами міжнародних організацій (МАГАТЕ, МКР3) та Директивами ЕС. Сучасні підходи до нормування радіаційних впливів на населення, персонал та навколишнє середовище, комплексний підхід до забезпечення радіаційного захисту є тими передумовами, на яких має базуватися нормативне регулювання безпеки.
Виходячи з наведеного огляду діяльності з радіонуклідної дефектоскопії, розгляду чинної нормативно-правової бази та сучасних документів МАГАТЕ і Директив ЄС, слід зазначити, що існуючі в Україні документи, які стосуються регулювання діяльності з дефектоскопії, не відповідають сучасним вимогам до забезпечення безпечного поводження з ДІВВ. При розробленні нового документа, який встановлюватиме вимоги безпеки до діяльності з гамма-дефектоскопії, необхідно базуватися на вимогах чинних вітчизняних нормативно-правових актів, враховувати рекомендації МАГАТЕ, Директиви $Є С$ та спиратися на сучасний вітчизняний та закордонний досвід.

\section{Список літератури}

1. Санитарные правила по радиоизотопной дефектоскопии № 1171-74

2. Норми радіаційної безпеки України (НРБУ-97). - Затвердж. наказом МО3 України від 14.07.1997 № 208; уведено в дію по становою Гол. держ. сан. лікаря України від 01.12.1997 № 62.

3. Основні санітарні правила забезпечення радіаційної безпеки України. - Затвердж. наказом МО3 України від 02.02.2005 № 54, зареєстр. в Мін’юсті України 20.05.2005 за № 552/10832.

4. МАГАТЭ. Международные основные нормы безопасности для защиты от ионизирующих излучений безопасного обращения с источниками ионизирующего излучения. Серия изданий по безопасности №115, Вена, 1997.

5. Вимоги та умови безпеки (ліцензійні умови) провадження діяльності $з$ використання джерел іонізуючого випромінювання (НП 306.5.05/2.065-2002). - Затвердж. наказом Держатомрегулювання від 02.12.02 № 125; зареєстр. в Мін’юсті України 17.12.02 за № 978/7266.

6. Вимоги до звіту про аналіз безпеки провадження діяль ності 3 використання джерел іонізуючого випромінювання (НП 306.5.05/2.066-2002). - Затвердж. наказом Держатомрегулювання від 02.12.02 № 125; зареєстр. в Мін’юсті України 17.12.02 за № $979 / 7267$.

7. Правила ядерної та радіаційної безпеки при перевезенні радіоактивних матеріалів (НП 306.6.124-2006). - Затвердж. наказом Держатомрегулювання України від 30.08.06 № 132; зареєстр. Мін’юстом України 18.09.2006 за № 1056/12930.

8. Правила забезпечення збереження ядерних матеріалів, радіо активних відходів, інших джерел іонізуючого випромінювання (НП 306.4.08/1.042-00). - Затвердж. наказом Мінекоресурсів України від 14.12.00 № 241; зареєстр. Мін’юстом України 12.01.01 за № $13 / 5204$.

9. Radiation Safety in Industrial Radiography, IAEA.

10. Радиоизотопные приборы, установки и радионуклидные источники / НОУ «Уч.-метод. центр экспертизы и сертификации». - Москва-Зеленоград, 2008.

Надійшла до редакції 04.08.2009. 